\title{
Scale-dependent influence of pre-existing basement shear zones on rift faulting: a case study from NE Brazil
}

\author{
J. D. KIRKPATRICK ${ }^{1,2 *}$, F. H. R. BEZERRA ${ }^{3}$, Z. K. SHIPTON ${ }^{4}$, A. F. DO NASCIMENTO ${ }^{3}$, \\ S. I. PYTHAROULI ${ }^{4}$, R. J. LUNN ${ }^{4} \&$ A. M. SODEN ${ }^{4,5}$ \\ ${ }^{1}$ School of Geographical and Earth Sciences, University of Glasgow, Glasgow, G12 8QQ, UK \\ ${ }^{2}$ Present address: Deportment of Earth and Planetary Sciences, University of California, Santa Cruz, CA 95064, USA \\ ${ }^{3}$ Department of Geophysics, Universidade Federal do Rio Grande do Norte, Natal, 59078-970, Brazil \\ ${ }^{4}$ Department of Civil and Environmental Engineering, University of Strathclyde, Glasgow, G40NG, UK \\ ${ }^{5}$ Present address: School of Geological Sciences, University College, Dublin 4, Ireland \\ *Corresponding author (e-mail: jkirkpat@ucsc.edu)
}

\begin{abstract}
Rifting of continental crust initiates faults that are commonly influenced by pre-existing structures. We document newly identified faults cutting Precambrian units in the interior of the NE Brazilian margin to assess the effects of structural inheritance on both rift geometry and fault architecture. Stratigraphic and structural data indicate that the faults were active in the main phase of rifting of Gondwana. The influence of pre-existing structures on the Mesozoic rift faulting is scale dependent. Regionally, the faults trend parallel to subvertical, crustal-scale Brasiliano (c. 750-540 Ma) shear zones. Mylonitic foliations and broadly distributed low strain in the lower crust indicated by shear-wave splitting controlled the overall orientation and kinematics of the rift faults. However, outcrop observations of the faults show that at scales up to hundreds of metres, mylonitic foliations have little influence on fault architectures. Faults cross-cut shear zones and do not commonly utilize foliation planes as shear fractures. Instead, slip zones and fractures have a range of orientations that form acute angles to the local foliation orientation. This observation explains the range of focal mechanisms associated with seismicity that coincides with ancient shear zones in intra-continental areas.
\end{abstract}

Rifting in intra-continental areas will commonly interact with a framework of pre-existing deformed zones. Although new structures form, structural inheritance may influence the location and geometry of tectonic deformation because strained rocks can act as weak zones localizing subsequent deformation (e.g. Watterson 1975; Sykes 1978; Handy 1989; Holdsworth et al. 2001). In particular, basins along rift margins are often inferred to be influenced by pre-existing structures (e.g. Daly et al. 1989; Lee \& Hwang 1993; van Wees \& Beekman 2000; Scheck-Wenderoth \& Lamarche 2005). The connection between basins and pre-existing structures is frequently based on the similarity of the trends of seismically imaged rift faults to basement tectonic trends observed onshore (e.g. Roberts \& Holdsworth 1999; Wilson et al. 2006). However, assessing the direct relationship between rift faults and pre-existing structures is often difficult because the basement is overlain by syn- to post-rift formations.

The effect of pre-existing structures on fault architecture at scales of tens to hundreds of metres is less clear. Some studies suggest that pre-existing foliations resulting from crystal-plastic deformation exert a strong influence on fault zone architecture during later deformation (e.g. Beacom et al. 2001; Butler et al. 2008). Experimental work indicates that foliated rocks are mechanically anisotropic (Donath 1964; Shea \& Kronenberg 1993), suggesting that foliations impart mechanical anisotropy or planes of weakness into the country rock that may be exploited by subsequent fracturing. However, analogues for the deeper sections of rift faults are rarely exposed, and the specific impacts of mechanical anisotropy for fault structures at exposure scale are consequently difficult to establish. Some insight into the nature of brittle structures overprinting ancient shear zones can be obtained from earthquake focal mechanisms. These frequently show that the brittle faults have varied orientations compared with the pre-existing foliation
(Bezerra et al. 2011; Pytharouli et al. 2011), hinting that the brittle phase of deformation involves greater complexity than straightforward reactivation of pre-existing foliation.

The NE Brazilian rift margin is an ideal location for assessing the importance of structural inheritance for both rift geometry and fault architecture because the pre-rift crystalline basement is exposed adjacent to onshore synrift formations (Fig. 1). The margin is composed of a series of intra-continental rift basins that formed during the break-up of Gondwana to form the South Atlantic (Matos 1992). Onshore basins contain Jurassic and Cretaceous syn- to post-rift sediments overlying a crystalline basement of Archaean to Neoproterozoic orthogneisses, paragneisses, schists and granitoids. Shear zones hundreds of kilometres in length formed during the Brasiliano orogeny, c. 750-540 Ma, deforming the basement (Brito Neves et al. 2000). These shear zones were pre-existing structures during Mesozoic rifting and potentially controlled the geometry of the rift basins. The coincidence in trend of the major basin-bounding faults and the basement shear zones has been noted previously (Matos 1992; De Castro et al. 2007, 2008, 2012), but direct correlation with exposures of faults cutting the basement has been limited by the lack of recognition of brittle faults in the basement rocks beyond the basin margins.

In this study we focus on the crystalline basement adjacent to the Mesozoic Potiguar rift basin (Fig. 1). We document a newly recognized system of brittle faults cutting the basement in the interior of the Brazilian rift margin. Remote sensing defines the faults at a regional scale and we use stratigraphic and structural criteria to demonstrate that the faults are syn- to post-rift. To assess the influence of the Precambrian shear zones on the rift, fault locations and fault architecture, we compare the distribution of Mesozoic faults with the shear zone distribution and present observations from key exposures of the faults to describe the fault 


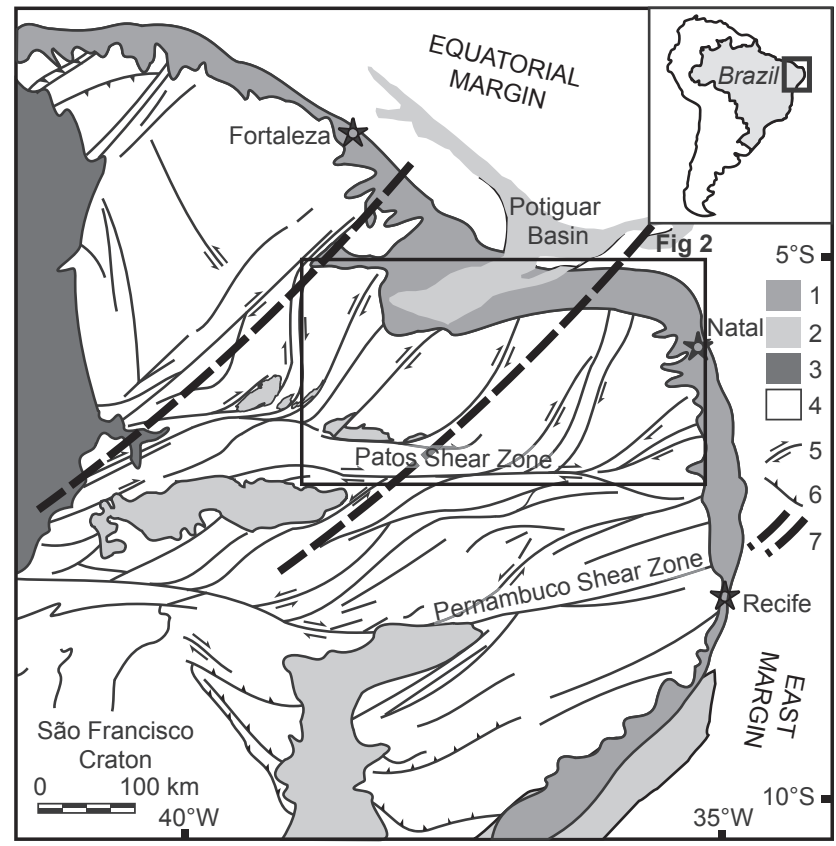

Fig. 1. Simplified tectonic map of NE Brazil showing the location (inset) and extent of the Borborema province, prominent shear zones and main sedimentary basins (modified from De Castro et al., 2008). The Potiguar basin and Cariri-Potiguar rift trend (between bold dashed lines) are the main focus of this study. Rectangle shows the location of Figure 2. 1,

Post-rift sedimentary cover; 2, Cretaceous basins; 3 , Palaeozoic basins; 4, Precambrian crystalline basement; 5, strike-slip ductile shear zones; 6 , thrust faults; 7, Cariri-Potiguar trend.

architecture. We find that the influence of the pre-existing structures is strongly scale dependent.

\section{Tectonic background of the continental margin of NE Brazil}

This study focuses on the region to the south and SW of the Mesozoic Potiguar basin in NE Brazil, where Archaean, Palaeoproterozoic and Neoproterozoic basement rocks of the Borborema Province crop out (Fig. 1). The Borborema Province consists of a collage of gneissic and granitic units sutured together by a system of Neoproterozoic shear zones and fold belts. The most pervasive deformation affecting the region occurred during the Brasiliano orogeny, associated with the amalgamation of western Gondwana (750-540 Ma; Brito Neves et al. 2000). Brasiliano deformation formed subvertical, strike-slip shear zones trending east-west to NE-SW and associated synkinematic granitic bodies. Existing Archaean to Neoproterozoic fabrics were reworked by the Brasiliano shear zones. Brasiliano shear zones are defined by steeply dipping mylonitic belts hundreds of kilometres long and up to tens of kilometres wide (Fig. 1; Brito Neves et al. 2000). Equivalent structures are present in the African margins and regional gravity data show that the lineaments corresponding to the Brasiliano shear zones and other terrane boundaries offset the Moho (De Castro et al. 2012).

The Potiguar basin formed during Mesozoic rifting of Gondwana (Matos 1992). Continental break-up between the South American and African plates occurred diachronously, beginning in the late Jurassic (c. $150 \mathrm{Ma}$; e.g. Nürenberg \& Muller, 1991). Two distinct margins developed on the South
American plate: the WNW-ESE-trending margin, referred to as the Equatorial Margin, and the NNE-SSW-trending margin, referred as the East Margin (Fig. 1; Matos 2000). The Equatorial Margin evolved as a transform margin, whereas the East Margin evolved as a classical divergent margin (Matos 1992, 2000). These two major rifts meet in the Borborema Province, the last part of South America to be separated from Africa.

The Potiguar basin is located at the northeastern end of the Cariri-Potiguar rift trend (Fig. 1) where the rift trend intersects the Equatorial Margin. The Cariri-Potiguar trend is one of several failed rifts that formed around the intra-continental edges of the Borborema Province during Mesozoic rifting, and is loosely defined by the distribution of Mesozoic basins (Fig. 2; Matos 1992) and by gravity data that indicate thinner crust along the trend compared with the surrounding shield (De Castro et al. 2012). Basin sediments record the onset of extension across the Potiguar basin during the Barremian (Matos 1992). The basin is subdivided into a set of asymmetric half-grabens separated by basement highs, transfer faults, and/or accommodation zones in both the northeastern offshore portion and southwestern onshore portion (Fig. 2). Major basin-bounding faults, such as the Carnaubais fault (see Fig. 2), have throws in excess of $5.5 \mathrm{~km}$ and clearly offset the crystalline basement in seismic images and gravity surveys (Matos 1992; De Castro et al. 2012). A series of smaller, intra-continental basins are exposed c. $150 \mathrm{~km} \mathrm{SW}$ of the southwestern edge of the Potiguar basin. Basins such as the Rio do Peixe, Icó and Iguatu contain Cretaceous fluvial and lacustrine sediments. Faults that controlled the formation of these intra-continental basins locally coincide with the basement tectonic fabric (Nóbrega et al. 2005; De Castro et al. 2007, 2008).

Throughout the Cenozoic, NE Brazil has experienced substantial uplift and erosion resulting in exhumation of both the rift margins and interior regions (Gallagher et al. 1994; Harman et al., 1998). Morais Neto et al. (2009) studied the broad pattern of landscape evolution of the Borborema Province using apatite fission-track analyses. They showed that the thermal history for the Borborema Province has two cooling events: one at c. $90-100 \mathrm{Ma}$ and one since c. $20 \mathrm{Ma}$. The older of these two events is associated with rifting and represents cooling of the crust to temperatures less than $100^{\circ} \mathrm{C}$. The younger corresponds to cooling from around $60^{\circ} \mathrm{C}$. However, more detailed studies indicate that the pattern of regional denudation is complicated by faulting, causing locally complex thermal histories (e.g. Nóbrega et al. 2005). Both studies are consistent with a broad pattern of $c .3 \mathrm{~km}$ of denudation since the main rift phase, with areas of higher denudation controlled by local tectonics.

Palaeoseismic and historical seismic records demonstrate that earthquakes in NE Brazil are influenced by the Brasiliano shear zones (Bezerra et al. 2011). Ferreira et al. (2008) and Lopes et al. (2010) documented seismicity with a range of focal mechanism orientations spatially coinciding with the Pernambuco shear zone towards the centre of the Borborema province. They concluded that the earthquake locations and kinematics were controlled by the shear zone mylonitic foliation. Closer to the Potiguar basin, several instances of reservoir-induced seismicity (RIS) are thought to have occurred on faults that coincide with pre-existing structures (Ferreira et al. 1995; Do Nascimento et al. 2004a, 2005; Ferreira et al. 2008; Pytharouli et al. 2011).

\section{Regional fault analysis}

We conducted a remote sensing survey of the regions south and SW of the Potiguar basin and identified 26 faults (Fig. 2). Faults were defined from air-photos and satellite images as continuous lineaments that offset lithological boundaries, or that formed 

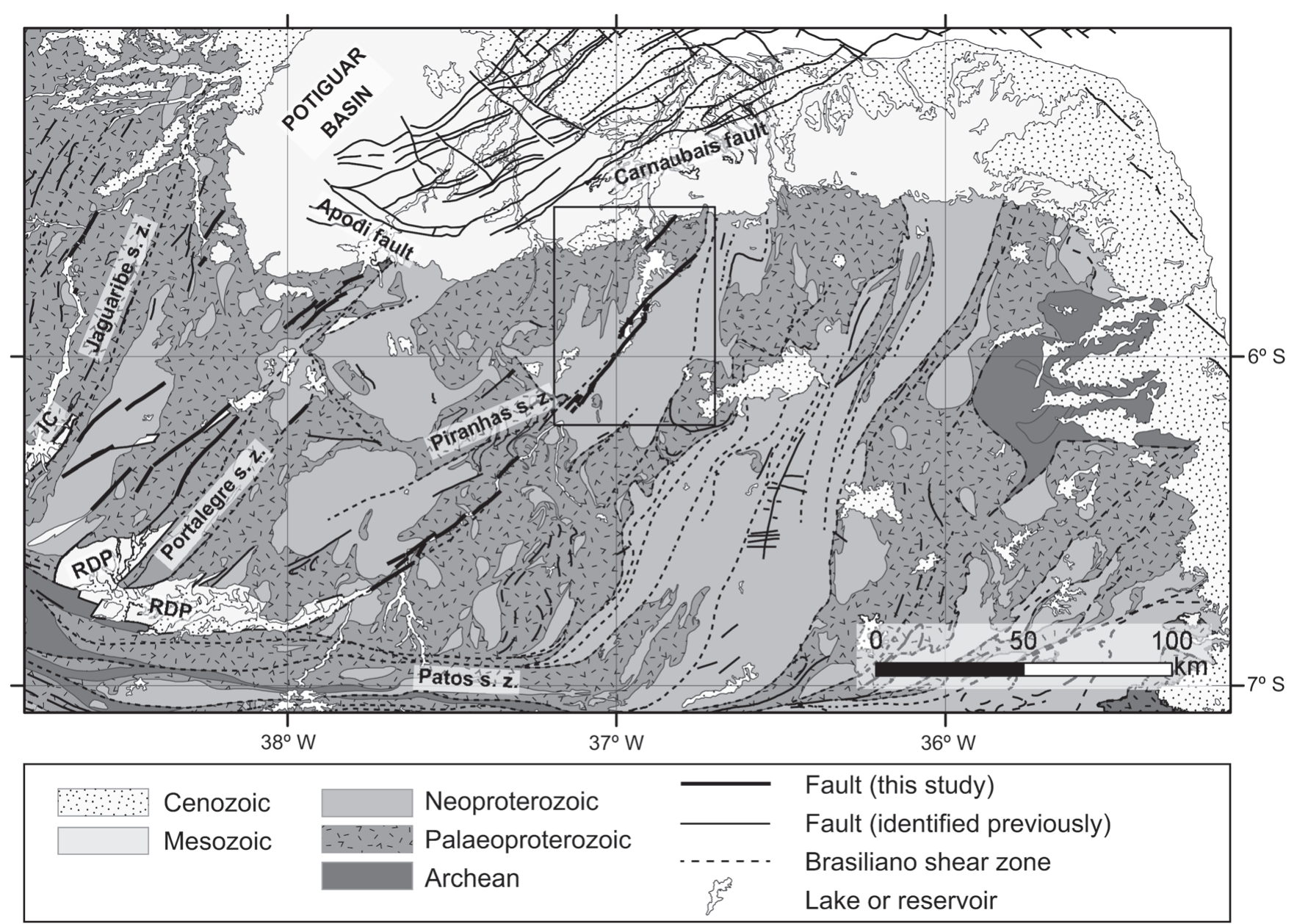

Fig. 2. Regional setting of the Potiguar basin and Cariri-Potiguar trend. Rift basins contain Mesozoic and Cenozoic sediments that overlie Neoproterozoic and Palaeoproterozoic crystalline units (RDP, Rio do Peixe basin; IC, Icó basin). Faults identified by remote sensing are shown as bold lines; the box shows the location of Figure 3. Previously identified faults (fine continuous lines) and major shear zones (dashed lines) are shown. The faults in the Potiguar basin are defined from seismic surveys and do not crop out at the surface.

prominent geomorphological traces in the landscape, typically gullies where the fault rock has been preferentially eroded. Additionally, one of the key criteria for identifying fault traces was the morphology of river channels, which are straight where they coincide with fault traces but meandering elsewhere. Airphotos predating the impoundment of the Assu reservoir, south of the Potiguar basin, were essential to this study as the reservoir covers a significant portion of the study area and also flooded much of the Rio Piranhas river channel coinciding with the Jucurutu fault (see below). Landsat ETM+ satellite images in RGB provided useful constraints where the faults affect the local groundwater flow regime and influence vegetation and weathering patterns. To confirm that the lineaments identified in the remote sensing survey correspond to brittle faults rather than dykes or joints, we visited three of the Rio Piranhas system faults and in each case verified lineaments as faults (see below; Fig. 3).

The Rio Piranhas fault system is located immediately south of the Potiguar basin. The northern part of the system includes three major fault strands trending $c$. 045-050 that are exposed along the Rio Piranhas river (Fig. 3): the Pataxós fault, São Rafael fault and Jucurutu fault. Further south, the system encompasses five additional strands that trend $c$. 050-060. Overall, the system spans $c$. $150 \mathrm{~km}$ along strike following the Rio Piranhas valley from the Rio do Peixe basin in the south to the Potiguar basin margin north of the Assu reservoir. The macro-scale geometry of the system is defined by straight fault traces $16-40 \mathrm{~km}$ in length with secondary faults developed at the ends of the main mapped fault traces at acute angles to the main fault segment trends. Observable offset markers are scarce: apparent dextral offset of $c .150 \mathrm{~m}$ across the São Rafael fault is indicated by the boundary of one granite pluton, but no piercing point data are available.

Approximately $80 \mathrm{~km}$ to the west of the Rio Piranhas system, the Cariri-Potiguar rift trends parallel to several crustal-scale shear zones (De Castro et al. 2012). Previous studies have suggested that the rift margin faults (e.g. Carnaubais fault) could trend onshore to the SW and reactivate pre-existing shear zones (Matos 1992; De Castro et al. 2012). We extended our remote sensing analyses to the west of the Rio Piranhas basin to establish if similar faults to those in the Rio Piranhas system could be identified in the rift trend elsewhere. Relief in the region is low and the area near the coast is heavily modified by agriculture. However, lineaments are present in the satellite imagery similar to those that define the faults in the Rio Piranhas system (Fig. 2). In particular, we have identified straight lineaments that coincide with the Portalegre and Jaguaribe shear zones. Based on the similarity in the geomorphological expressions of the lineaments to the Rio Piranhas system faults, as well as some 


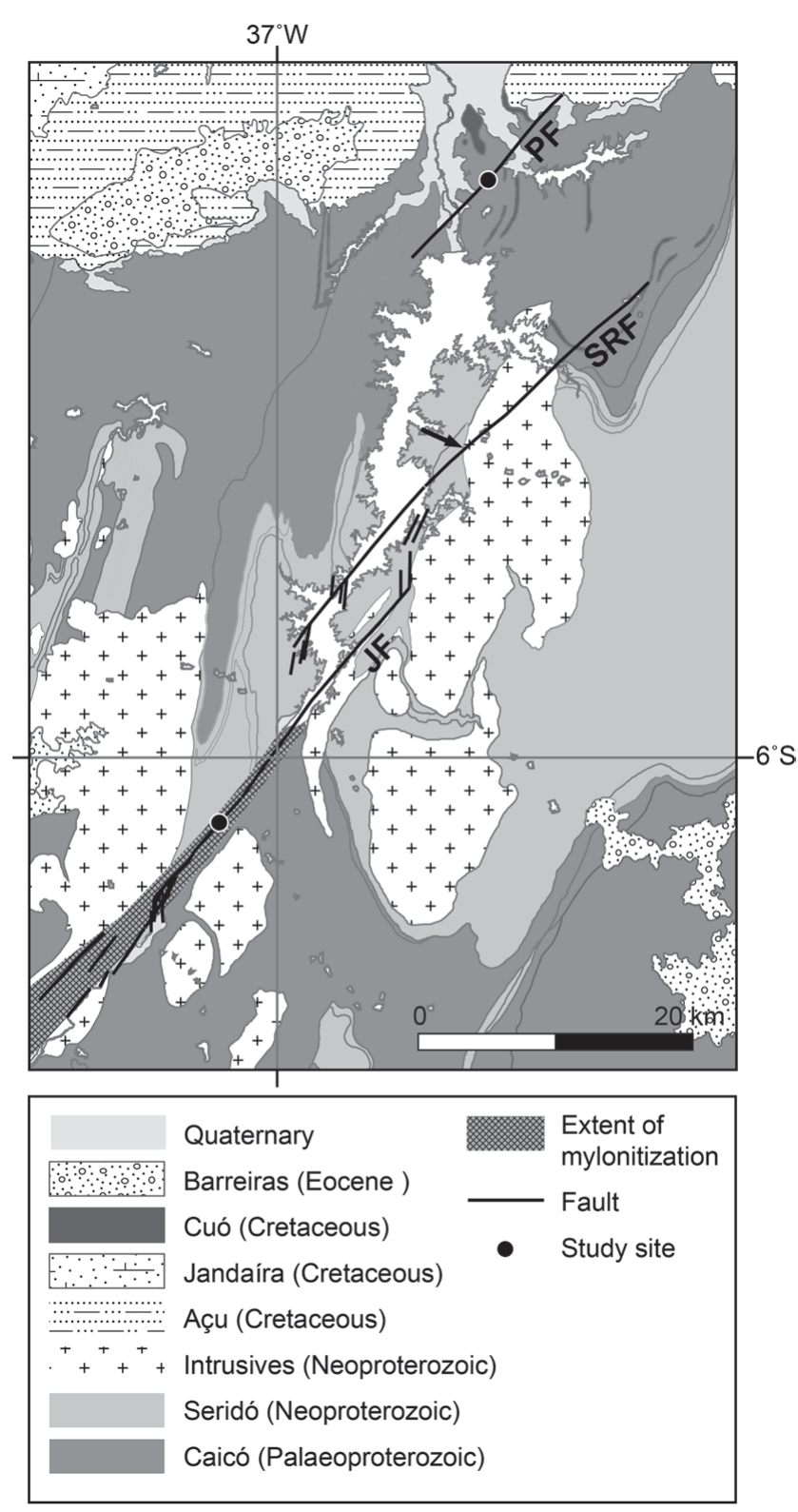

Fig. 3. Detailed map of the Rio Piranhas fault system. Faults were mapped from satellite images and air-photos and were visited in the field. PF, Pataxós fault; SRF, São Rafael fault; JF, Jucurutu fault. The extent of mylonitization associated with the Piranhas shear zone is indicated by grey shading. The black arrow shows the location of observed $150 \mathrm{~m}$ apparent dextral offset of a pluton boundary.

lineaments cross-cutting the basement geological contacts and tectonic fabrics, we interpret the new lineaments as faults.

\section{Field and microscope observations}

In this section we present field and microscope observations of the Piranhas shear zone and two of the best exposed faults of the Rio Piranhas system to evaluate the relationship between brittle faulting and basement shear zones. We focus on the deformation mechanisms and alteration assemblages associated with brittle deformation in the faults to estimate the depth at which the faults were active and constrain the timing of faulting (detailed in the 'Interpretation' section).

\section{Piranhas shear zone}

The Piranhas shear zone is one of a series of structures of $100 \mathrm{~km}$ scale that deform the crystalline basement in NE Brazil (Fig. 2). The shear zone trends $c .043$ in the northeastern part of its trace, and $050-060$ in the SW, and affects both basement gneisses and synkinematic granites in the study area south of the Assu reservoir.

We observed the northern extent of the shear zone in the field at the southern study site indicated in Figure 3. Sheared granite in the margin of the pluton adjacent to the main trend of the shear zone consists of $\sigma$-type vein quartz tails around feldspar porphyroclasts in a fine-grained quartz groundmass containing an $\mathrm{S}-\mathrm{C}$ fabric, a composite fabric made up of aligned shear bands (Passchier \& Trouw 2005), indicating dextral shear (Fig. 4). Where the gneissic country rock is deformed, it forms equigranular, fine-grained (c. $200 \mu \mathrm{m})$, bluish-grey, quartzo-feldspathic mylonites with a steeply dipping mylonitic foliation $\left(75-90^{\circ}\right)$. The foliation strikes subparallel to the overall shear zone trend, but locally varies by up to $10^{\circ}$ at the $10 \mathrm{~m}$ scale. Folded quartz and epidote veins, as well as veins that are not folded cross-cut the foliation at low angles. Stretching lineations defined by elongate quartz grains are subhorizontal in the plane of the foliation. The mylonites contain millimetre-scale compositional banding defined by relatively quartz-rich and feldspar-rich layers. Thin section examination shows that quartz grains are mostly euhedral to subhedral with straight grain boundaries and frequent triple junctions. Euhedral quartz grains show little evidence for dynamic recrystallization. However, subhedral grains with occasional serrated grain boundaries show subgrain growth by subgrain rotation recrystallization and sweeping undulose extinction. Plagioclase feldspar grains are heavily altered to sericite but show some evidence for undulose extinction and subgrain rotation recrystallization. Aligned chlorite and muscovite grains define the mylonitic foliation at micro-scale. This foliation is also parallel to compositional banding and a weak grain shape fabric defined by aligned quartz and feldspar grains. Chlorite layers wrap around feldspar porphyroclasts that have weakly defined quartz tails (Fig. 4).

\section{Rio Piranhas system faults}

The northernmost fault of the Rio Piranhas system, the Pataxós fault, has a mapped trace length of $c .16 \mathrm{~km}$ defined by remote sensing (Fig. 3). The Pataxós fault trends NE from the Assu dam towards the Potiguar basin. Good exposures are located where the fault crosses highway BR304 and the Pataxós canal (shown in Fig. 3), both of which display an approximately vertical fault zone. The gneissic banding in the wall rock is subhorizontal at both exposures. At the canal exposure $\left(5^{\circ} 37.282^{\prime} \mathrm{S}, 36^{\circ} 51.547^{\prime} \mathrm{W}\right)$, the fault juxtaposes Palaeoproterozoic Caicó formation biotite gneiss and Cuó metavolcanic rocks (c. 99 Ma). Further to the NE, the fault trends towards the Potiguar basin and cuts the post-rift Assu formation in satellite images.

The Pataxós fault comprises a $c .18 \mathrm{~m}$ thick fault core surrounded by numerous subsidiary structures (Fig. 5). Several distinct, incohesive, friable fault gouges define the fault core. The predominant gouge is purple-grey and consists of millimetre- to tens of micrometres scale grains of plagioclase and alkali feldspars, quartz and occasional fragments of muscovite (Fig. 5b and d). Randomly oriented calcite veins cross-cutting the gouge, pervasive alteration of plagioclase to white mica or calcite, and fragments of cataclased veins within the gouge record sustained neo-mineralization. In some places feldspars in the gouge have been completely replaced with calcite. Strain is localized onto millimetre-thick shear bands that link grains replaced by phyllosilicates. Two localized strands of finer-grained, slightly darker coloured gouge up to $10 \mathrm{~cm}$ wide 

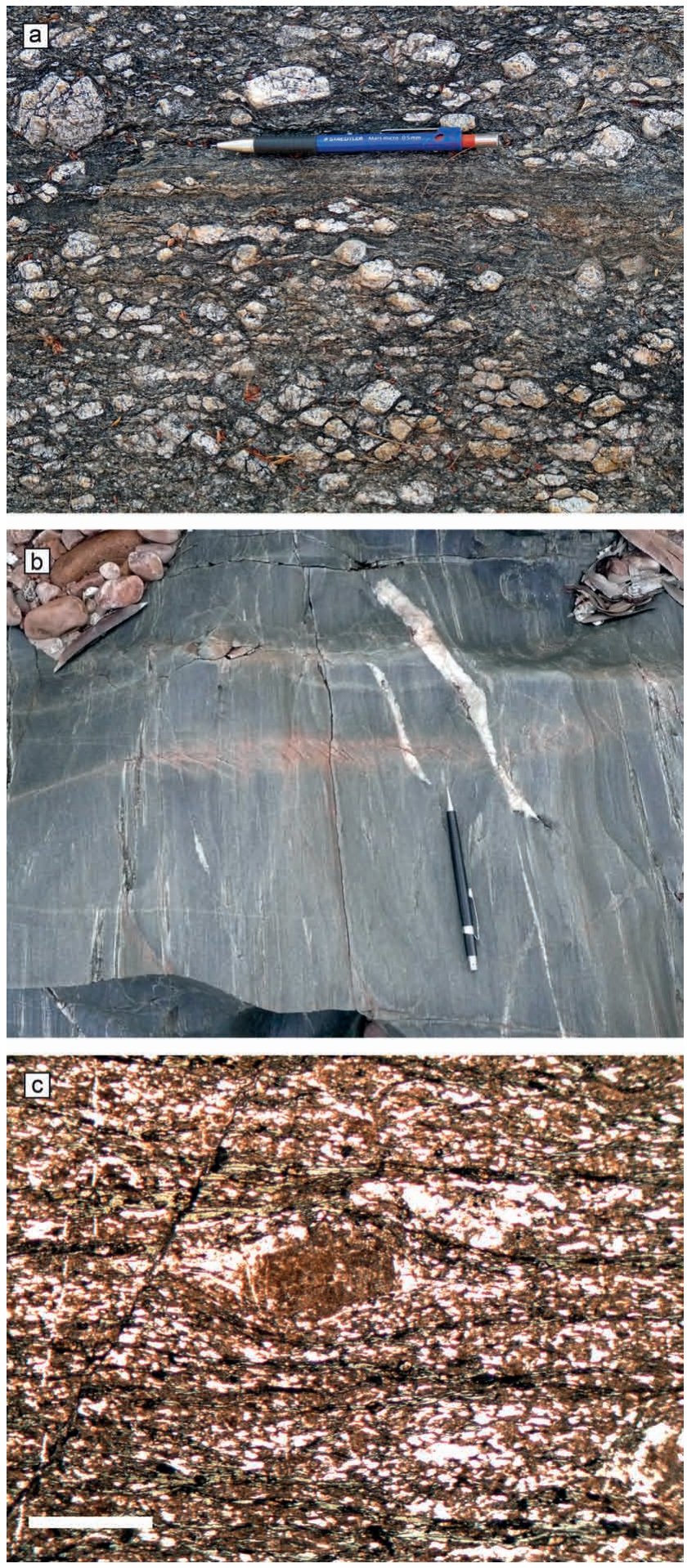

Fig. 4. Mylonites of the Piranhas shear zone. (a) Sheared granite containing plagioclase porphyroclasts with $\sigma$-type vein quartz tails and a weakly developed S-C fabric in the groundmass. (b) Mylonites with millimetre-scale compositional banding parallel to mylonitic foliation (indicated by pencil) cross-cut by quartz veins. (c) Photomicrograph (plane-polarized light) showing plagioclase porphyroclasts with small quartz tails. Chlorite and muscovite bands (horizontal) wrap around the porphyroclast. The pervasive alteration of feldspars should be noted (scale bar $1 \mathrm{~mm}$ ). cross-cut the main body of purple-grey gouge. These strands are subparallel to the overall fault orientation and are not subsequently deformed. The dark colour of the cross-cutting gouges results from a high proportion of metal oxides in the gouge matrix. The matrix oxides are predominantly anhedral, filling spaces between quartz grains in the matrix and smaller clasts.

Subsidiary structures surrounding the fault core include joints and small offset $(\leq 1 \mathrm{~m})$ faults. The subsidiary faults dip $80-90^{\circ}$, and rakes of slickenlines and orientations of corrugations on exposed slip surfaces indicate net oblique-dip slip offsets. The cataclasites in the subsidiary faults are a few centimetres to $1.5 \mathrm{~m}$ thick and have variable grain-size distributions with the coarsest grains reaching from $0.5 \mathrm{~mm}$. All of the cataclasites have a distinct reddish-purple hue, and thin section analysis shows they contain a significant proportion of opaque metal oxides, similar to the most recently slipped strands of the main fault core (Fig. 5c).

South of the Assu reservoir, the Rio Piranhas river channel follows the trace of the Jucurutu fault. The river channel morphology is segmented into straight portions between stretches where the river meanders (Fig. 3). Exposed bedrock in one straight portion of the river shows that the channel morphology is constrained by the preferentially eroded Jucurutu fault. Air-photos that predate the impoundment of the Assu reservoir show that the fault continues along a northeasterly trend under the modern reservoir level and forms a left step with the São Rafael fault. The total trace length is around $40 \mathrm{~km}$. No offset markers have been observed. To the south of the Assu reservoir, the Jucurutu fault trends approximately parallel to the mylonites of the Piranhas shear zone (041).

The internal architecture of the Jucurutu fault is characterized by a fault core zone containing fault breccias, cataclasites and pseudotachylytes flanked by an extensive damage zone. The core zone is asymmetrical around a strand of mixed cataclasite and pseudotachylyte that is continuous over hundreds of metres along strike, crosscutting all of the other deformation elements (Fig. 6). Both edges of the core are non-planar with predominant wavelength of tens of metres and both edges locally cross-cut the mylonitic foliation at low to moderate angles. Although heterogeneous along strike, damage zone fracture frequency is consistently highest close to the core, and decays with distance from the fault core defining a total damage zone width of $c .100 \mathrm{~m}$. The damage zone is dominated by closely spaced $(<10 \mathrm{~cm})$, annealed, unmineralized steeply dipping fractures. It also contains short, epidote-filled fractures, which display apparent shear offset and contain epidote-cemented cataclasites. Unmineralized and mineralized fractures in the damage zone tend to run at a high angle to both the foliation and fault trends, with a minor subset of fractures that run parallel to the foliation (Fig. 6). Subsidiary faults branch from the core zone and extend up to $100 \mathrm{~m}$ along strike. Subsidiary faults show both apparent sinistral and dextral sub-metre-scale offsets and contain indurated quartzepidote-chlorite cataclasites with angular to rounded clasts of mylonite and quartz veins tightly cemented with a compacted epidote and quartz matrix.

Cataclasites in the continuous fault core strand are cemented with an aphanitic purple-grey crystalline material. This material contains rounded and embayed fragments of mylonite and cataclasite in an aphanitic, brown to black matrix that displays flowbanding textures consistent with altered pseudotachylytes (Fig. 6). Where the fault core strand is narrow, the cataclasites are absent and the strand is completely filled with the purple-grey pseudotachylyte. Veins with chaotic geometries and orientations in the wall rock adjacent to the fault core are also filled with pseudotachylytes. The cataclasites consist of random-fabric, angular to subrounded clasts of host rock mylonites and fragments of previously formed cataclasite in a matrix dominated by epidote and 

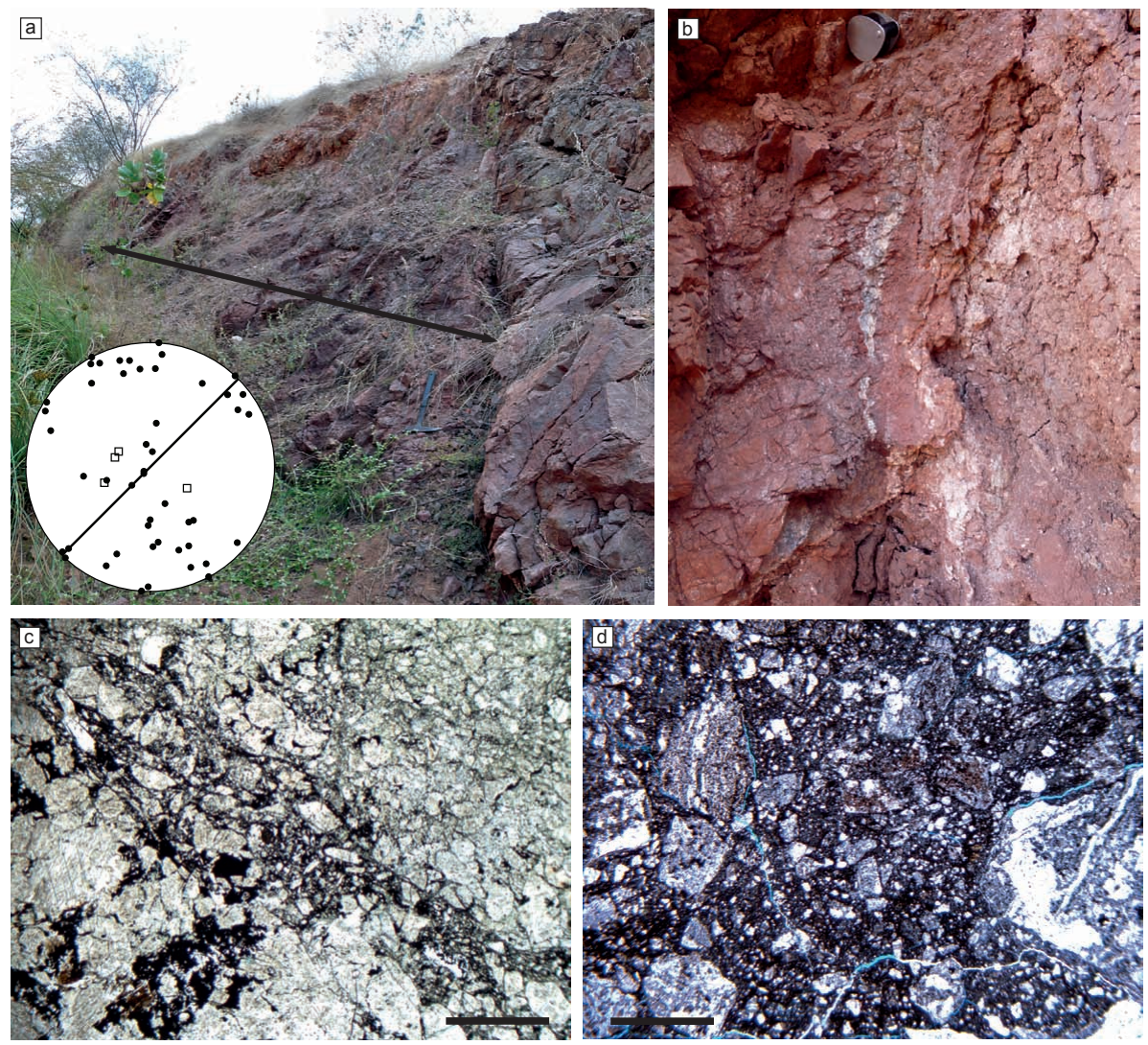

Fig. 5. The canal exposure of the Pataxós fault. (a) The fault core of the Pataxós fault is defined by a series of friable gouges and has a total thickness of $c .18 \mathrm{~m}$ (indicated by the black arrow; hammer for scale in the foreground). The stereonet (lower hemisphere, equal area) shows the overall orientation of the fault (bold great circle), poles to foliation in the wall rock biotite gneiss (open squares, $n=4$ ), and poles to damage zone fractures (filled circles, $n=45$ ). (b) Detail of one of the localized gouge strands that cross-cuts the other gouges of the fault core. Calcite veins (white) are parallel to the local foliation in the gouge and subparallel to the overall fault orientation (hand lens for scale). (c) Photomicrograph of the damage zone cataclasite showing high proportion of anhedral metal oxides filling space between clasts. Feldspars in the clasts are heavily altered and are often replaced by calcite (scale bar $1 \mathrm{~mm}$ ). (d) Photomicrograph of the gouge in (b) showing the random fabric, and rounded clasts of quartz and feldspar. Metal oxides are also abundant in the matrix of the gouge (scale bar $1 \mathrm{~mm}$ ). chlorite, similar to the subsidiary faults. Adjacent to the cataclasite strand, a zone of fault breccia $c .5 \mathrm{~m}$ wide contains at least five types of breccias as defined by clast-matrix proportions, matrix composition, clast shapes and cross-cutting relationships. Strands of breccias splay from the core zone at angles of $c .25-30^{\circ}$ counterclockwise from the fault trace. All of the breccias that are cross-cut by the main fault core strand are also cemented with pseudotachylyte, indicating multiple melt-generating events.

\section{Interpretation}

\section{Depth of deformation}

Deformation mechanisms and synkinematic growth of chlorite and muscovite in the Piranhas shear zone record mid-crustal, greenschist-facies conditions. Feldspars show evidence for subgrain rotation recrystallization where they are not pervasively altered. Quartz is extensively recrystallized in the granites, and shows some evidence for subgrain rotation recrystallization in the mylonites. Crystal-plastic deformation of quartz and plagioclase together indicates temperatures of the order of $450{ }^{\circ} \mathrm{C}$ (e.g. Tullis \& Yund 1987). We interpret the straight grain boundaries of the equigranular quartz grains lacking crystal-plastic deformation as evidence for static recrystallization. In addition to the alteration of feldspars, the textures in the mylonites are consistent with the latest stages of the retrograde Brasiliano deformation (see Araújo et al. 2003).

We estimate the depth of faulting on the Rio Piranhas faults by using the deformation products to constrain the temperature at which the most recent elements of the fault rocks formed. Many of the faults contain fragments of rocks formed at high temperatures (mylonites, gneisses), but these are cross-cut by cataclastic deformation products with no evidence for intra-crystalline plasticity in any of the dominant mineral phases (quartz and feldspars). The complete absence of crystal-plastic deformation mechanisms throughout the brittle faulting implies that the faults were active at less than $c .280-300{ }^{\circ} \mathrm{C}$ (e.g. Stipp et al. 2002), equivalent to depths of less than $c .9 \mathrm{~km}$ for a typical geothermal gradient of c. $30^{\circ} \mathrm{Ckm}^{-1}$.

Indurated and welded cataclasites in which the predominant minerals are chlorite and epidote characterize the Jucurutu fault. Fault rocks with propylitic assemblages such as this are typically interpreted to represent temperatures of $c .200-300{ }^{\circ} \mathrm{C}$ or more, corresponding to depths of over $c .7 \mathrm{~km}$ for geothermal gradients of $25-30^{\circ} \mathrm{C} \mathrm{km}^{-1}$ (Guilbert \& Park 1986; Bruhn et al. 1994). The development of pseudotachylytes in the fault core of the Jucurutu fault is consistent with slip at mid-crustal depth, as pseudotachylyte generation is promoted by higher shear stresses (Sibson \& Toy 2006).

The Pataxós fault is characterized by friable, random-texture fault gouges. Angular grains that underwent fracture, frictional sliding and rolling and that are loosely packed are typical of faulting in the upper few kilometres (i.e. $2-5 \mathrm{~km}$ ) of the crust (Sibson 1977). Comparable textures are found in faults where the depth is well constrained by sedimentary cover (e.g. Chester \& Chester 1998). Plagioclase is progressively altered to calcite in the Pataxós fault gouge and damage zone cataclasites. This synkinematic alteration is consistent with deformation at shallow crustal levels (c. $100-150^{\circ}$ C; e.g. Boles 1982; Blenkinsop \& Sibson 1992).

\section{Shear zone and fault kinematics}

A variety of kinematic indicators have been identified for the studied structures that point to a complex deformation history. All kinematic indicators in the Piranhas shear zone indicate dextral shear, consistent with previous descriptions (e.g. Vauchez et al. 1995). Feldspar porphyroclasts with $\sigma$-type quartz tails are contained 

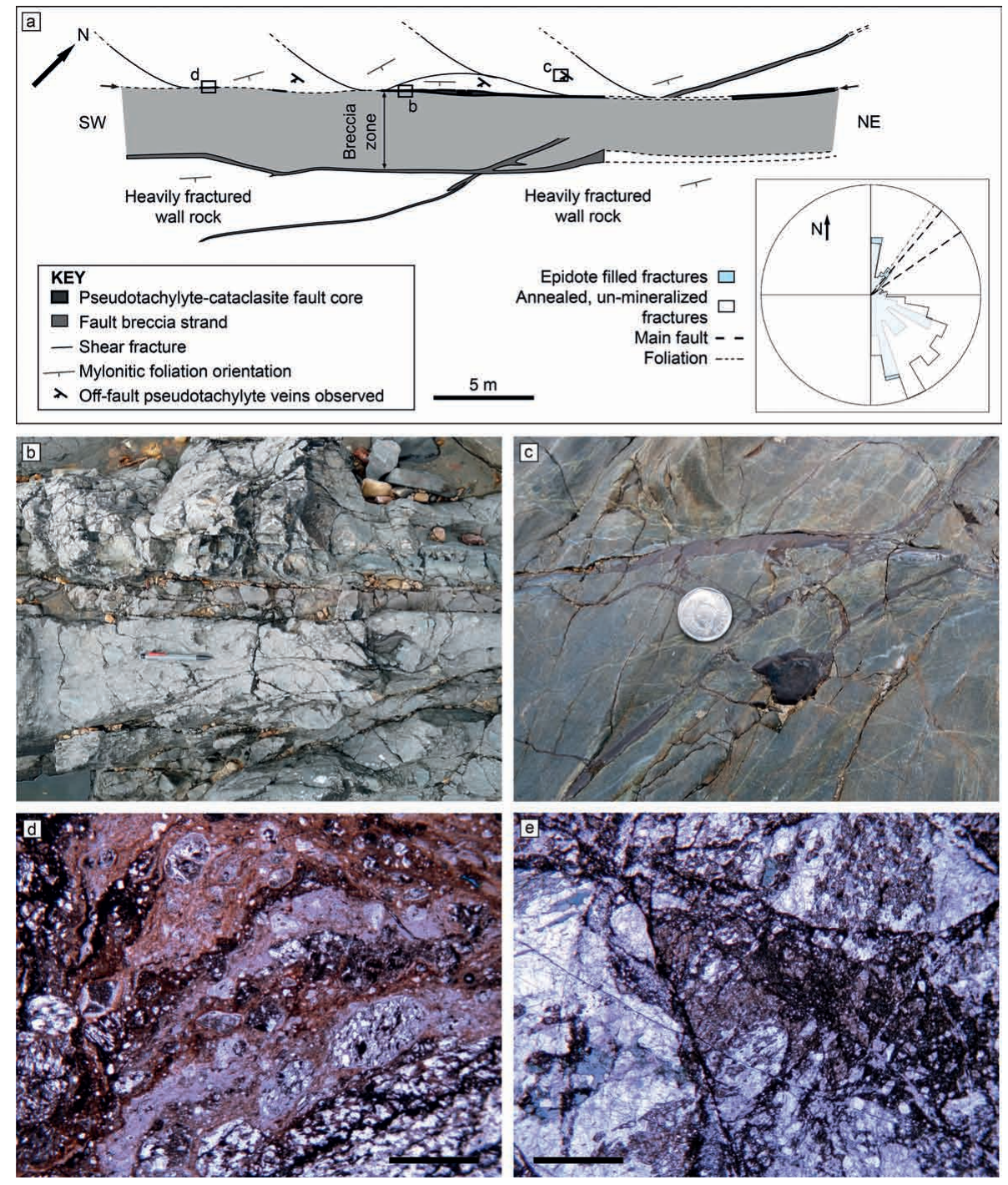

Fig. 6. Architecture and composition of the Jucurutu fault. (a) Baseline map showing the internal architecture of the Jucurutu fault. Multiple cataclasites and breccias define the core zone, which is flanked by an extensive damage zone. Pseudotachylytes mixed with cataclasites define a continuous strand of intensely deformed rock (between arrows). The rose diagram shows the range of Jucurutu fault orientations measured in exposure (bold dashed lines), general foliation orientation (fine dashed lines) and the strikes of fractures in the damage zone $(n=1196)$. (b) A continuous strand of mixed cataclasite and pseudotachylyte crosscuts all other components of the fault (above pencil). (c) Chaotic veins filled with homogeneous, aphanitic purple-grey material cross-cut the foliation in the host rock immediately adjacent to the core zone (coin for scale is c. $25 \mathrm{~mm}$ diameter). (d) Photomicrograph of the mixed cataclasite and pseudotachylyte. Flow banding in an otherwise cryptocrystalline matrix is prominent. Rounded and embayed clasts are composed of wall rock mylonite and also fragments of previously formed cataclasites. Scale bar $1 \mathrm{~mm}$. (e) Photomicrograph of the indurated cataclasite that defines the damage zone subsidiary faults. It should be noted that the location of (e) is not shown in (a) because the sample was obtained c. $30 \mathrm{~m}$ off-fault. The fine-grained matrix (black) is composed of comminuted mylonite and contains abundant epidote and quartz (scale bar $1 \mathrm{~mm}$ ). within synkinematic granites that are dated to $580-550 \mathrm{Ma}$ (Angelim et al. 2006), demonstrating that the Piranhas shear zone was active during the Brasiliano orogeny. However, the kinematics of the brittle phase of deformation are less clear. At the macroscale, the Rio Piranhas system is segmented into main strands separated by left steps. Secondary faults in this system are oriented at acute, counterclockwise orientations to the main strands, consistent with apparent sinistral motion. In contrast, the one offset marker identified in the field is an offset pluton boundary NE of the Assu reservoir that is apparently dextrally offset by the São Rafael fault.

At the exposure scale, the Jucurutu fault has a meso-scale architecture in which the orientations of the breccia strands are consistent with apparent sinistral motion. However, the subsidiary faults (with the same mineral assemblage as the core cataclasites and breccias) have orientations showing both apparent dextral and sinistral strikeslip offsets more consistent with normal motion on the fault (see Fig. 6; note that the vertical component of offset cannot be gauged from these annealed features as there are no appropriate markers). Fewer kinematic indicators have been identified in the subvertical Pataxós fault. Slickenlines and corrugations on damage zone subsidiary faults have oblique-dip slip rakes (rakes $>50^{\circ}$ ) and would be consistent with oblique-normal displacement on the fault. Overall, the fault orientations, architectures and populations of damage zone fractures point to predominantly strike-slip deformation overprinted by oblique normal displacement. However, each fault contains contradictory indicators, which we interpret to indicate that the faults formed under an oblique strike-slip regime with a component of normal displacement, consistent with observations of other transtensional settings (Woodcock 1986; De Paola et al. 2005).

\section{Timing of faulting}

Establishing the timing of activity on the Rio Piranhas fault system and the other study area faults is critical for placing the faults in the wider context of the tectonic development of the continental margin of NE Brazil. The faults represent brittle deformation that could have formed either as a late stage of the Brasiliano-related deformation, during Mesozoic rifting that formed the South Atlantic, or during an unknown phase of Cenozoic tectonic activity.

At the northern end of the Rio Piranhas system, field and remote sensing results indicate that the Pataxós fault cuts the c. 99 Ma Cuó volcanic rocks and post-rift sediments of the Assu formation. The Pataxós fault is the only fault that we visited in the field that clearly cuts Mesozoic or younger units. However, at the southern end of the Rio Piranhas system, the faults identified by remote sensing trend into the Rio do Peixe basin, which contains Cretaceous synrift formations (Françolin et al. 1994; De Castro et al. 2007). The continentally derived fluvial and lacustrine synrift formations are structurally 
controlled by the Rio Peixe fault, which was active during the Cretaceous. Although we have not confirmed the linkage between the Rio Peixe fault and the Rio Piranhas system faults in the field, the strikes of the Rio Piranhas system faults rotate towards ENEWSW, and near the Rio do Peixe basin are close to collinear with the Rio Peixe fault at the basin margin (see De Castro et al. 2007). The collinearity of the faults and the timing of fault activity where it can be stratigraphically constrained are the same and suggest contemporaneous deformation on all of the Rio Piranhas and Rio Peixe faults.

The timing of faulting can also be inferred from depth if the exhumation history of the area is known. The variety of deformation products we observe in the Rio Piranhas faults suggests that the faults have been exhumed to different extents, similar to other rift margins (e.g. Argent et al. 2002). The apatite fission-track study of Morais Neto et al. (2009) includes localities adjacent to the Jucurutu fault near Jucurutu village and Angicos, c. $30 \mathrm{~km}$ to the east of the trace of the Pataxós fault. These samples both show two cooling events: cooling through $100^{\circ} \mathrm{C}$ at c. $100 \mathrm{Ma}$ and through $60^{\circ} \mathrm{C}$ since $c$. $20 \mathrm{Ma}$. Assuming a geothermal gradient of $20-30{ }^{\circ} \mathrm{C} \mathrm{km}^{-1}$ (see Lisker 2004), the older event defines the time at which the rocks now exposed at the surface were at $c .3-5 \mathrm{~km}$ depth. Comparing these results with our microstructural observations, the Pataxós fault rocks formed at $c .100-150{ }^{\circ} \mathrm{C}$ and therefore formed at or around $100 \mathrm{Ma}$. The Jucurutu fault rocks formed at $>200^{\circ} \mathrm{C}$ were also formed by c. $100 \mathrm{Ma}$ although their exhumation must have been more rapid since then. The available thermochronology therefore supports the interpretation that the Jucurutu fault and Pataxós fault were both active during the Cretaceous rifting.

We infer that the faults that we identified to the west of the Rio Piranhas system were active at the same time as the Rio Piranhas faults. The western faults show similar relationships to both the Brasiliano shear zones (the Portalegre and Jaguaribe shear zones) and other intra-continental basins. The faults are macroscopically parallel to the rift trend, the shear zone trends, and also the generally steeply dipping mylonitic foliation orientation. Several faults close to the Cretaceous Icó and Rio do Peixe basins are probably the along-strike extension of the Mesozoic basin-bounding faults (e.g. De Castro et al. 2008). The consistent pattern arising from the remote sensing is that brittle faulting is frequently expressed in the geomorphology within the Cariri-Potiguar rift trend, and the faults are continuations of structures bounding the isolated interior basins.

In summary, all of the new faults that we describe in the Rio Piranhas system and the faults to the west of the Rio Piranhas within the Cariri-Potiguar rift trend are likely to have been active during the main phase of rifting. This interpretation is consistent with previously published thermochronological analyses (e.g. Nóbrega et al. 2005). Although brittle faulting would have accompanied Brasiliano deformation in the Precambrian, the Brasiliano shallow crustal section has been eroded, exposing the mid-crustal shear zones. There is no evidence that the faults formed by continuous retrograde deformation associated with the late stages of the Brasiliano shear zones.

\section{Discussion}

\section{Regional context: Cariri-Potiguar rift trend}

We have identified and mapped new faults cutting crystalline rocks to the south and SW of the Potiguar basin (Figs 2 and 3). The faults probably have complex deformation histories, but the depth and inferred timing of the youngest phases of deformation, allied with offset Cretaceous post-rift sediments, indicate that all of the faults we describe are Mesozoic rift faults. The amount and sense of displacement on each of the faults is difficult to establish. However, typical fault thickness-displacement scaling relationships indicate that the
Pataxós fault and Jucurutu fault (the faults for which we have good constraints on fault core thickness) probably accommodated hundreds of metres to kilometres of displacement (e.g. Childs et al. 2009).

From a regional perspective, the Rio Piranhas system trends SW from the Potiguar basin margin to the Rio do Peixe basin in the south (Fig. 3). Remote sensing results suggest that the Jucurutu fault links to the Rio do Peixe basin-bounding faults. Basal Rio do Peixe sedimentary units are Neocomian conglomerates and sandstones (Françolin et al. 1994; De Castro et al. 2007) that are the same age as the earliest rift sediments in the Potiguar basin. Extension across the Potiguar basin and Rio do Peixe basin was therefore contemporaneous and it seems likely that the entire Rio Piranhas system was active at this time.

Similarly, the fault traces identified in satellite images that coincide with the Portalegre and Jaguaribe shear zones to the west of the Rio Piranhas system link the Potiguar basin with the interior Iguatu and Icó basins. Furthermore, the Portalegre shear zone is immediately along-strike from the major Potiguar basin-bounding fault, the Carnaubais fault, and brittle fault segments coinciding with the Portalegre trend could be an along-strike extension of the Carnaubais fault (Nóbrega et al. 2005; De Castro et al. 2012). This is consistent with the basement offsets imaged seismically on the Carnaubais fault (Matos 1992) that demonstrate that the rift faults do cut the basement. Iguatu and Icó sediments are also Neocomian (Matos 1992) so the fault systems throughout the Cariri-Potiguar trend that link these basins with the Potiguar basin were also likely to have been active synchronously. If this is the case, it suggests that the role of the Apodi fault as the southwestern termination structure to the Potiguar basin, as has been suggested previously (Matos 1992), is incorrect. The Apodi fault is probably more similar to the other NW-SE-trending transfer faults within the basin.

The broad distribution and contemporaneous deformation throughout the Cariri-Potiguar trend to the SW of the Potiguar basin indicates that the amount of extension across the basementhosted interior portion of the failed rift is greater than has been appreciated. This deformation is difficult to identify because postrift uplift has caused any rift sediments deposited in the region to have been eroded and the remaining inverted basins are isolated and dispersed. Throughout the majority of the region, faults are restricted to crystalline basement rocks and are rarely exposed. Lineaments defined in regional gravity and magnetic surveys indicate that the shear zones in the crystalline basement extend to the base of the crust (De Castro et al. 2012). We suggest that extension across the Mesozoic Cariri-Potiguar rift contributes to the anomalies in the geophysical data associated with the Brasiliano shear zones. Our results also imply that basins were developed along the length of the Cariri-Potiguar trend and that the Potiguar basin was probably linked to the other small grabens such as Rio do Peixe, Icó and Iguatu in the Cretaceous.

\section{Rift and fault architecture}

The close association of the brittle faults and ductile shear zones in the deeply exhumed crystalline rocks south of the Potiguar basin provides an opportunity to examine the role of pre-existing structures on localizing subsequent deformation. The Brasiliano shear zones are hundreds of kilometres long and ubiquitously display subvertical mylonitic foliations. Isotopic dating of synkinematic granites shows that the shear zones throughout the region, including the Piranhas shear zone, were active at 750-540 Ma (Brito Neves et al. 2000). Offsets in the Moho imaged in regional gravity surveys demonstrate that many of the shear zones are crustal in scale and have counterparts in Africa that correspond to the same palaeo-structures (de Wit et al. 2008; De Castro et al. 2012). 
Mesozoic rifting therefore deformed continental crust that contained pre-existing highly strained shear zones.

At the regional scale many of the Mesozoic rift faults we mapped trend parallel to the Brasiliano shear zones. Macroscopically, the Jucurutu fault is parallel to the Piranhas shear zone that it overprints (trending c. 043 at the study location). Further to the south, the trends of faults in the Rio Piranhas system rotate to strike $050-060$ as they coincide with a shear zone trending in a more NNE-SSW orientation near the Rio do Peixe basin. To the west, faults defined in the remote sensing survey trend parallel to the Portalegre and Jaguaribe shear zones. Geometric similarity between brittle faults and the shear zones in the basement is a common characteristic of many of the faults in the region, and, as pointed out previously, the overall orientations of the Potiguar basin-bounding faults are typically collinear with crustal-scale anomalies in magnetic and gravity data (De Castro et al. 2012). The shear zone orientations do therefore influence the subsequent rift fault orientations. As the regional stress field must have been different during the continent-building Precambrian Brasiliano orogeny and Mesozoic rifting, faults oriented parallel to the shear zones would have been poorly oriented relative to the regional stress field at the time of rifting. Transtensional faulting would have been likely during rifting, consistent with our kinematic data.

In contrast to the system-scale geometry of the rift, meso-scale characteristics of the fault architectures are only weakly influenced by pre-existing tectonic foliations. The fault core zone of the Jucurutu fault has non-planar edges with roughness amplitudes of tens of centimetres at the $10 \mathrm{~m}$ wavelength scale. Orientations of the edge of the core zone and the edge of the cataclasite and breccia strands in the fault are consequently locally at acute angles to the mylonitic foliation (typically $10-30^{\circ}$ ). Locally, the foliation planes are not parallel to fault slip surfaces. Similarly, the country rock cut by the São Rafael fault and Pataxós fault is folded at tens or hundreds of metres wavelength, but the orientation of the fault does not change, resulting in higher angles between the faults and wall rock gneissic banding (up to $60-90^{\circ}$ ). Damage zone subsidiary faults and fracture orientations in the Jucurutu fault also show only a minor degree of influence from the mylonitic foliation, represented as minor populations of fractures that form parallel and perpendicular to the foliation. This pattern is also evident in the damage zone of the Pataxós fault and the São Rafael fault, which both contain only small populations of foliation-parallel fractures.

These observations suggest that the influence of pre-existing structures is scale dependent. At the regional scale, the macroscopic orientations of rift faults are broadly parallel to shear zone trends. This is consistent with previous inferences that such foliated shear zones are inherently weak compared with low-strain regions (e.g. Watterson 1975; Handy 1989). However, we suggest that the fault orientations are controlled mainly by the shear zone foliations, which present mechanical anisotropy defined at the grain scale. For example, the Jucurutu fault has been exhumed by up to $7 \mathrm{~km}$ since it was active during rifting (temperatures of $200-300^{\circ} \mathrm{C}$ ), so the mid-crustal conditions during rifting are exposed. The Jucurutu fault cuts the quartz- and feldspar-dominated Piranhas shear zone, which contains only minor components of phyllosilicates. A grain shape fabric and compositional banding define the mylonitic fabric where phyllosilicates are absent. Grain boundary alignment, compositional banding and minor alignment of phyllosilicates, rather than other mechanisms such as dynamic grain-size reduction, resulted in long-term weakening. This observation is consistent with experiments on anisotropic rocks that show that foliated rocks such as gneisses are weaker in the plane of the foliation even where the phyllosilicate content is low (e.g. Shea \& Kronenberg 1993) and suggests that strain at mid- to lower crustal depths will strongly influence subsequent brittle deformation regardless of the composition of the mylonites.
Several of the faults of the Rio Piranhas system are not co-located with shear zones and do not have mylonitic wall rocks, yet their orientations are consistent with the overall rift geometry. The São Rafael fault and Pataxós fault cross-cut gneisses, marbles and schists with subhorizontal or folded foliations (gneissic banding or schistosity). Mylonite development in high-strain zones is not the primary control on the orientation of these structures. However, shear-wave splitting observed in the vicinity of the Assu reservoir (where shear zones are not mapped) shows seismic anisotropy oriented parallel to the Piranhas shear zone, even where rocks exposed at the surface are not mylonitized (Do Nascimento et al. 2004b). The seismic anisotropy is caused by a pervasive foliation in the shallow crust beneath the reservoir. The volume of crust causing the shear-wave splitting has been exhumed since the main rift phase; in the Mesozoic it would have been at $5-10 \mathrm{~km}$ depth or more. The coincidence of the fault orientations and mechanical anisotropy suggests that the fault orientations of the São Rafael fault and Pataxós fault are controlled by broadly distributed Brasiliano strain in the lower crust, even though this is not immediately apparent in exposure. Grain-scale fabrics in low-strain zones therefore also controlled subsequent brittle fault orientation and kinematics.

The meso-scale architecture of the rift faults that cross-cut foliated rocks is characterized by features with a variety of orientations with respect to the foliation (Fig. 7). These features are the product of the total displacement on the faults. We suggest that brittle deformation is initially controlled by the grain-scale anisotropy observed in the field, resulting in mechanical anisotropy and broadly parallel incipient brittle and pre-existing structures (see Crider \& Peacock 2004). However, various processes cause faults to develop and maintain complexity with increasing displacement, resulting in fault architectures that are apparently little influenced by the pre-existing structures. Childs et al. (2009) showed that fault segment linkage, fault rock development and damage accumulation are all spatially variable and would give rise to brittle structures that are not parallel to the foliation. Local variations in foliation orientation (e.g. by folding) are observed within the Piranhas shear zone and would promote non-coplanar fault segments, requiring steps and jogs to develop as faults accumulate displacement. Furthermore, fault roughness is maintained during deformation (Brodsky et al. 2011), resulting in slip zones that are non-planar and non-parallel to the initial foliation. Faults that co-locate with shear zones may initially reactivate the foliation in the sense of developing shear surfaces along the foliation planes, but the coincidence of orientations is quickly obliterated. For mature faults, direct extrapolation of mechanical anisotropy observed experimentally cannot be made to the exposure scale because it would neglect the effects of meso-scale processes that dominate fault architecture.

The observations of faults with slip zones and subsidiary structures at a variety of orientations that cross-cut shear zones with pronounced foliations help to reconcile the apparent contradiction in focal mechanisms of small magnitude, intra-plate earthquakes that co-locate with shear zones but that indicate that faults have slipped at various angles to the shear zone orientation (e.g. Lopes et al. 2010; Bezerra et al. 2011). The earthquakes coincide with shear zones containing prominent foliations. However, the focal mechanisms of the earthquakes have a variety of orientations, indicating that brittle structures cross-cut the local foliation orientations. Anisotropic elastic properties affect seismic-wave propagation and so would add additional complexity to the focal mechanisms of events in foliated rocks (e.g. Vavryčuk 2005; Timms et al. 2010), but our exposurescale observations show that faults have slip surfaces and damage zone subsidiary structures in a range of orientations that are only weakly influenced by any pre-existing foliations. There are a therefore a variety of structures that can slip during earthquakes, resulting 


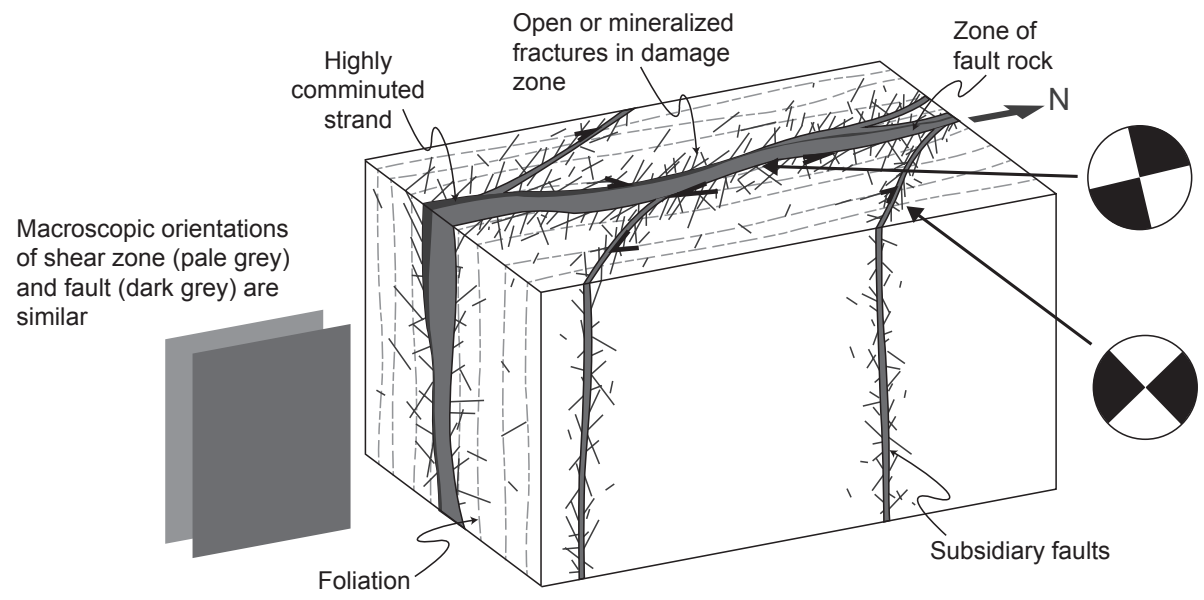

Fig. 7. Conceptual model of a fault developed in a region with a pre-existing shear zone defined by mylonitic foliation. The macroscopic orientations of the fault and shear zone (shown by the squares on the left) are similar, as the grain-scale mechanical anisotropy in the mylonite controls the nucleation of fractures. Although local variations in mylonite fabric orientation occur, the overall orientation is regionally consistent. Fault rocks, slip zones and subsidiary structures are non-planar and form at a range of orientations. As a result, the fault structures locally appear at acute angles to the foliation (bold lines show the variety of angles observed in the field). Damage zone fractures have a range of orientations consistent with the fault kinematics, with a minor population parallel to the foliation. Two focal mechanisms are shown to indicate the differences that could arise if small-magnitude earthquakes localized on different parts of the fault structure.

in a wide range of potential focal mechanisms. Furthermore, if the faults cut rocks with foliations that are variable at the meso-scale, the orientation of the fault will not necessarily relate to the foliation.

\section{Conclusions}

We document newly identified faults that cut crystalline basement rocks in the interior of the continental margin of NE Brazil. Regional-scale remote sensing results show that the faults link the Mesozoic Potiguar rift basin with smaller remnant basins in the continental interior. Offset post-rift sediments, combined with estimates of the depth of faulting from microstructural analyses, demonstrate that the newly identified faults are syn- to post-rift. The basement was pervasively deformed in the Precambrian during the Brasiliano orogeny, which formed crustal-scale, subvertical shear zones. These shear zones represented a framework of pre-existing structures at the time of rifting. We show that the system-scale geometry of the rift faults correlates well with the orientations of the shear zones. Faults frequently co-locate with major shear zones and are macroscopically parallel to the trends of the shear zones. Even where the faults do not locally cut mylonitic rocks they are parallel to the regional trends. Mylonitization imparted a grain shape fabric and compositional banding onto the high-strain rocks in the shear zones, which was sufficient to localize subsequent deformation. Seismic anisotropy observed from shear-wave splitting in the study area is oriented parallel to the shear zone trends and suggests that broadly distributed low strain also controlled the orientations of faults that do not cross-cut shear zones. Deep exhumation in the margin interior has exposed faults that are the along-strike equivalent of the deeper sections of rift basin faults. At the exposure scale the faults in the basement are only weakly influenced by the pre-existing tectonic fabrics, highlighting a scale-dependent response to the structural inheritance. The system-scale rift geometry is therefore controlled by pre-existing strained rocks, but meso-scale processes in brittle faults result in structures that locally cross-cut foliations. This detail is reflected in earthquake focal mechanisms observed in rifted margin settings that coincide with shear zones but suggest faults at various angles to the shear zone trends.

J.K., Z.S., S.P., R.L. and A.S. were supported by NERC grant NE/E005365/1. F.H.R.B. was supported by INCT-ET/CNPq and A.F.d.N. was supported by INCT/CNPq Petroleum Geophysics; both of them hold research grants from CNPq-Brazil. A.F.d.N. also acknowledges CNPq grant 483349/2007-0. Thoughtful reviews by F. Brozzetti and D. Healy improved the paper greatly. We thank C. Rowe for helpful discussions and insightful comments on this paper.

\section{References}

Angelim, L.A.A., Medeiros, V.C. \& Nesi, J.R. 2006. Geological Map of the State of Rio Grande do Norte, Brazilian Geological Survey-CPRM, 500000 scale. Brazilian Ministry of Energy (MME), Recife [in Portuguese].

Araújo, M.N.C., da Silva, F.C.A., Jardim de SA, E.F., Holcombe, R.F. \& DE VAsconcelos, P.M. 2003. Microstructural evolution of the Seridó Belt, NE Brazil: The effect of two tectonic events on development of c-axis preferred orientation in quartz. Journal of Structural Geology, 25, 2089-2107, doi:10.1016/S0191-8141(03)00069-5.

Argent, J.D., Stewart, S.A., Green, P.F. \& Underhill, J.R. 2002. Heterogeneous exhumation in the Inner Moray Firth, UK North Sea: Constraints from new AFTA and seismic data. Journal of the Geological Society, London, 159, 715-729.

Beacom, L.E., Holdsworth, R.E., McCaffrey, K.J.W. \& Anderson, T.B. 2001. A quantitative study of the influence of pre-existing compositionaland fabric heterogeneities upon fracture zone development during basement reactivation. In: Holdsworth, R.E., Strachan, R.A. \& Magloughlin, J.F. (eds) The Nature and Tectonic Significance of Fault Zone Weakening. Geological Society, London, Special Publications, 186, 195-211.

Bezerra, F.H.R., Do Nascimento, A.F., ET AL. 2011. Review of active faults in the Borborema Province, intraplate South America integration of seismological and paleoseismological data. Tectonophysics, 510, 269-290, doi.org/10.1016/j.tecto.2011.08.005.

Blenkinsop, T.D. \& Sibson, R.H. 1992. Aseismic fracturing and cataclasis involving reaction softening within core material from the Cajon Pass drill hole. Journal of Geophysical Research, 97, 5135-5144.

Boles, J.R. 1982. Active albitization of plagioclase, Gulf Coast Tertiary. American Journal of Science, 282, 165-180.

Brito Neves, B.B., Santos, E.J. \& Van Schmus, W.R. 2000. Tectonic history of the Borborema Province, Northeastern Brazil. In: Cordani, U.G., Milani, E.J., Thomaz Filho, A. \& Campos, D.A. (eds) Tectonic Evolution of South America. Proceedings of the 31st International Geological Congress, Rio de Janeiro. 151-182.

Brodsky, E.E., Gilchrist, J.J., Sagy, A. \& Collettini, C. 2011. Faults smooth gradually as a function of slip. Earth and Planetary Science Letters, 302, 185-193, doi:10.1016/j.epsl.2010.12.010.

Bruhn, R.L., Parry, W.T., Yonkee, W.A. \& Thompson, T. 1994. Fracturing and hydrothermal alteration in normal fault zones. Pageophysics, 142, 609-644.

Butler, R.W.H., Bond, C.E., Shipton, Z.K., Jones, R.R. \& CASey, M. 2008. Fabric anisotropy controls faulting in the continental crust. Journal of the Geological Society, London, 165, 449-452, doi:10.1144/0016-76492007-129.

Chester, F.M. \& Chester, J.S. 1998. Ultracataclasite structure and friction processes of the San Andreas fault. Tectonophysics, 295, 199-221.

Childs, C., Manzocchi, T., Walsh, J.J., Bonson, C.G., Nicol, A. \& Schöpfer, M.P.J. 2009. A geometric model of fault zone and fault rock thickness 
variations. Journal of Structural Geology, 31, 117-127, doi:10.1016/j. jsg.2008.08.009.

Crider, J.G. \& Peacock, C.P. 2004. Initiation of brittle faults in the upper crust: a review of field observations. Journal of Structural Geology, 26, 691-707, doi:10.1016/j.jsg.2003.07.007.

Daly, M.C., Chorowicz, J. \& Fairhead, J.D. 1989. Rift basin evolution in Africa: the influence of reactivated step basement shear zones. In: COOPER, M.A. \& Williams, C.D. (eds) Inversion Tectonics. Geological Society, London, Special Publications, 44, 309-334.

De Castro, D.L., Oliviera, D.C. \& Castelo Branco, R.M.G. 2007. On the tectonics of the Neocomian Rio do Peixe rift basin, NE Brazil: Lessons from gravity, magnetics and radiometric data. Journal of South American Earth Sciences, 24, 184-202, doi.org/10.1016/j.jsames.2007.04.001.

De Castro, D.L., Bezerra, F.H.R. \& Branco, R.M.G.C. 2008. Geophysical evidence of crustal-heterogeneity control of fault growth in the Neocomian Iguatu basin, NE Brazil. Journal of South American Earth Sciences, 26, 271-285.

De Castro, D.L., Bezerra, F.H.R., Sousa, M.O.L. \& Fuck, R.A. 2012. Influence of Neoproterozoic tectonic fabric on the origin of the Potiguar Basin, northeastern Brazil and its links with West Africa based on gravity and magnetic data. Journal of Geodynamics, 54, 29-42, doi:org/10.1016/j. jog.2011.09.002.

De Paola, N., Holdsworth, R. \& McCaffrey, K.J.W.E. 2005. The influence of lithology and pre-existing structures on reservoir-scale faulting patterns in transtensional rift zones. Journal of the Geological Society, London, 162, 471-480, doi:10.1144/0016-764904-043.

De Wit, M.J., Stankiewicz, J. \& Reeves, C. 2008. Restoring Pan-AfricanBrasiliano connections: more Gondwana control, less Trans-Atlantic corruption. In: Pankhurst, R.J., Trouw, R.A.J., Brito Neves, B.B.D. \& De Wit, M.J. (eds) West Gondwana: Pre-Cenozoic Correlations across the South Atlantic Region. Geological Society, London, Special Publications, 294, 399-412, doi: $10.1144 /$ SP294.20.

Donath, F.A. 1964. A strength variation and deformational behavior of anisotropic rocks. In: RuDD, W.R. (ed.) State of Stress in the Earth's Crust. Elsevier, New York, 281-297.

Do Nascimento, A.F., Cowie, P.A., Lunn, R.J. \& Pearce, R.G. $2004 a$ Spatiotemporal evolution of induced seismicity at Açu reservoir, NE Brazil. Geophysical Journal International, 158, 1041-1052, doi:10.1111/j.1365-246X.2004.02351.x.

Do Nascimento, A.F., Bezerra, F.H.R. \& Takeya, M.K. 2004b. Ductile Precambrian fabric control of seismic anisotropy in the Açu dam area, northeastern Brazil. Journal of Geophysical Research, 109, B10311, doi:10.1029/2004JB003120.

Do Nascimento, A.F., Lunn, R.J. \& Cowie, P. 2005. Modeling the heterogeneous hydraulic properties of faults using constraints from reservoirinduced seismicity. Journal of Geophysical Research, 110, B09201, doi: 10.1029/2004JB003398.

Ferreira, J.M., Oliveira, R.T., Assumpção, M., Moreira, J.A.M., Pearce, R.G. \& TAKEYA, M.K. 1995. Correlation of seismicity and water level in the Açu reservoir - an example from northeast Brazil. Bulletin of the Seismological Society of America, 85, 1438-1489.

Ferreira, J.M., Bezerra, F.H.R., Sousa, M.O.L., Do Nascimento, A.F., Sá, J.M. \& FrançA, G.S. 2008. The role of Precambrian mylonitic belts and presentday stress field in the coseismic reactivation of the Pernambuco lineament, Brazil. Tectonophysics, 456, 111-126.

Françolin, J.B.L., Cobbold, P.R. \& Szatmari, P. 1994. Faulting in the Early Cretaceous Rio do Peixe Basin (NE Brazil) and its significance for the opening of the Atlantic. Journal of Structural Geology, 16, 647-661.

Gallagher, K., Hawkesworth, C.J. \& Mantovani, M.S.M. 1994. The denudation history of the onshore continental margin of SE Brazil inferred from apatite fission track data. Journal of Geophysical Research, 99, $18117-18145$

Guilbert, J.M. \& Park, C.F. 1986. The Geology of Ore Deposits. Freeman, New York.

Handy, M. 1989. Deformation regimes and the rheological evolution of fault zones in the upper lithosphere: The effects of pressure, temperature, grainsize and time. Tectonophysics, 163, 119-152.

Harman, R. R., Gallagher, K., Brown, R., Raza, A. \& Bizzi, L. 1998 Accelerated denudation and tectonic/geomorphic reactivation of the cratons of northeastern Brazil during the Late Cretaceous. Journal of Geophysical Research, 103, 27091-27105.

Holdsworth, R.E., Stewart, M., Imber, J. \& Strachan, R. 2001. The structure and rheological evolution of reactivated continental fault zones: A review and case study. In: Miller, J.A., Holdsworth, R.E., Buick, I.S. \& Hand, M. (eds) Continental Reactivation and Reworking. Geological Society, London, Special Publications, 184, 115-137.
Lee, M.J. \& Hwang, Y.J. 1993. Tectonic evolution and structural styles of the East Shetland Basin. In: PARKer, J.R. (ed.) Petroleum Geology of Northwest Europe, Proceedings of the 4th Conference. Geological Society, London, $1137-1149$

LisKeR, F. 2004. The evolution of the geothermal gradient from Lambert Graben and Mahanadi Basin - a contribution to the Indo-Antarctic rift debate. Gondwana Research, 7, 363-373.

Lopes, A.E.V., Assumpcão, M., Do Nascimento, A.F., Ferreira, J.M., Menezes, E.A.S. \& BARBOSA, J.B. 2010. Intraplate earthquake swarm in Belo Jardim, NE Brazil: Reactivation of a major Neoproterozoic shear zone (Pernambuco Lineament). Geophysical Journal International, 180, 1303-1312, doi:10.1111/j.1365-246X.2009.04485.x.

Matos, R.M.D. 1992. The northeast Brazilian rift system. Tectonics, 11, 766-791.

Matos, R.M.D. 2000. Tectonic evolution of the Equatorial South Atlantic. In: Mohriak, W. \& Taiwani, M. (eds) Atlantic Rifts and Continental Margins. American Geophysical Union, Geophysical Monograph, 115, 331-354.

Morais Neto, J.M., Hegarty, K.A., Karner, G.D. \& Alkmim 2009. Timing and mechanisms for the generation and modification of the anomalous topography of the Borborema Province, northeastern Brazil. Marine and Petroleum Geology, 26, 1070-1086, doi:10.1016/j.marpetgeo.2008.07.002.

Nóbrega, M.A., SÁ, J.M., ET AL. 2005. The use of apatite fission track thermochronology to constrain fault movements and sedimentary basin evolution in northeastern Brazil. Radiation Measurements, 39, 627-633.

NürenberG, D. \& Muller, R.D. 1991. The tectonic evolution of the South Atlantic from Late Jurassic to present. Tectonophysics, 191, 27-53, doi:10.1016/0040-1951(91)90231-G.

Passchier, C.W. \& Trouw, R.A.J. 2005. Microtectonics. Springer, Berlin.

Pytharouli, S.I., Lunn, R.J., Shipton, Z.K., Kirkpatrick, J. \& Do Nascimento, A.F.D. 2011. Microseismicity illuminates fluid pathways in the shallow crust. Geophysical Research Letters, 38, L02402, doi:10.1029/2010GL045875.

Roberts, A.M. \& Holdsworth, R.E. 1999. Linking onshore and offshore structures: Mesozoic extension in the Scottish Highlands. Journal of the Geological Society, London, 156, 1061-1064.

Scheck-Wenderoth, M. \& Lamarche, J. 2005. Crustal memory and basin evolution in the Central European Basin System-new insights from a 3D structural model. Tectonophysics, 397, 143-165, doi:10.1016/j. tecto.2004.10.007.

Shea, W.T. \& Kronenberg, A.K. 1993. Strength anisotropy of foliated rocks with varied mica contents. Journal of Structural Geology, 15, 1097-1121.

SiBSon, R.H. 1977. Fault rocks and fault mechanisms. Journal of the Geological Society, London, 133, 191-213, doi:10.1144/gsjgs.133.3.0191.

Sibson, R.H. \& Toy, V.G. 2006. The habitat of fault-generated pseudotachylyte: presence vs. absence of friction-melt. In: ABERCROMBIE, R.E., McGarr, A., Di Toro, G. \& Kanamori, H. (eds) Earthquakes: Radiated Energy and the Physics of Faulting. American Geophysical Union, Geophysical Monograph, 170, 153-166.

Stipp, S., Stünitz, H., Heilbronner, R. \& Schmid, S.M. 2002. The eastern Tonale fault zone: A 'natural laboratory' for crystal plastic deformation of quartz over a temperature range from 250 to $700^{\circ} \mathrm{C}$. Journal of Structural Geology, 24, 1861-1884.

SyKeS, L.R. 1978. Intraplate seismicity, reactivation of pre-existing zones of weakness, alkaline magmatism, and other tectonism postdating continental fragmentation. Reviews in Geophysicas and Space Physics, 16, 621-688.

Timms, N.E.D., Healy, D., Reyes-Montes, J.M., Collins, D.S., Prior D.J. \& Young, R.P. 2010. Effects of crystallographic anisotropy on fracture development and acoustic emission in quartz. Journal of Geophysical Research, 115, B07202, doi:10.1029/2009JB006765

Tuluis, J. \& Yund, R.A. 1987. Transition from cataclastic flow to dislocation creep of feldspar: Mechanisms and microstructure. Geology, 15, 606-609.

van WeEs, J.D. \& BeEKMAn, F. 2000. Lithosphere rheology during intraplate basin extension and inversion; inferences from automated modeling of four basins in western Europe. Tectonophysics, 320, 219-242.

Vauchez, A., Neves, S.P., ET AL. 1995. The Borborema shear zone system. Journal of South American Earth Sciences, 8, 247-266.

VAVRYČUK, V.2005. Focal mechanisms in anisotropic media. Geophysical Journal International, 161, 334-346, doi:10.1111/j.1365-246X.2005.02585.x.

Watterson, J. 1975. Mechanism for the persistence of tectonic lineaments. Nature, 253, 520-522, doi:10.1038/253520b0

WiLson, R.W., McCAFfrey, K.J.W., ET AL. 2006. Complex fault patterns, transtension and structural segmentation of the Lofoten Ridge, Norwegian margin: Using digital mapping to link onshore and offshore geology. Tectonics, 25, TC4018, doi:10.1029/2005TC001895.

Woodсоск, N.H. 1986. The role of strike-slip fault systems at plate boundaries. Philosophical Transactions of the Royal Society of London, Series A, 317, 13-29. 